\title{
Herbal High: Substance-Induced Psychosis after Consumption of Seeds of the Hawaiian Baby Woodrose
}

\author{
Esther Sobanski1,2, Saskia Dalm², Luisa Sievers², Tim Külzer², Heinz Liesenfeld², \\ Halgard Schmidt-Kittler², and Michael Huss ${ }^{1,2}$ \\ Department of Child and Adolescent Psychiatry and Psychotherapy, University Medical Center Mainz, Germany \\ Department of Child and Adolescent Psychiatry, Psychosomatics and Psychotherapy, Rheinhessen Clinics, Mainz, Germany
}

\begin{abstract}
Seeds of the Hawaiian Baby Woodrose (HBWR, Argyreia nervosa) are known as "legal or herbal highs" and can be easily purchased online in Germany. They contain various ergot alkaloids, including lysergic acid amide (LSA), which is chemically related to lysergic acid diethylamide (LSD). Pharmacological data are limited but suggest that LSA-concentration in HBWR seeds is highly variable, and that adverse psychiatric and somatic effects are not related to LSA-dosage. Anecdotal, mostly cross-sectional clinical case reports describe spontaneous remission of intoxication-related somatic and psychiatric symptoms as well as intoxication-related death. Treatment recommendations for LSA-induced psychiatric syndromes are not available. We report here on the clinical course and treatment of a drug-induced psychosis after consumption of HBWR seeds. The adolescent had consumed HBWR seeds once before without suffering any negative effects.
\end{abstract}

Keywords: drug-induced psychosis, legal high, herbal high, Hawaiian Baby Woodrose, lysergic acid diethylamide

\section{Herbal High: Substanzinduzierte Psychose nach dem Konsum von Samen der Hawaiianischen Holzrose}

\begin{abstract}
Zusammenfassung: Samen der Hawaiianischen Holzrose (Argyreia nervosa) sind als sog. "legale Highs" in Deutschland frei verkäuflich. Sie enthalten u.a. die psychoaktiv wirksame Substanz Lysergsäureamid (LSA), die chemisch Lisergsäurediethylamid (LSD) ähnelt. Verfügbare pharmakologische Daten deuten daraufhin, dass die LSA-Konzentration in den Samen der Hawaiianischen Holzrose stark schwankt sowie dass eine dosisunabhängige Intoxikation auftreten kann. Zur Klinik der Intoxikation mit Samen der Hawaiianischen Holzrose sind wenige anekdotische Fallberichte veröffentlicht worden, die überwiegend eine rasche, spontane Remission der im Zuge der Intoxikation auftretenden psychiatrischen und somatischen Symptomatik, aber auch eine Intoxikation mit Todesfolge beschreiben. Behandlungsempfehlungen bei LSA-induzierten psychiatrischen Störungen sind nicht verfügbar. Wir berichten hier über Symptomatik, Verlauf und medikamentöse Behandlung einer drogeninduzierten schizophrenen Psychose nach Konsum von Samen der Hawaiianischen Holzrose bei einer 17-jährigen Patientin. Die Jugendliche hatte im Vorfeld bereits einmal Samen der Hawaiianischen Holzrose ohne Nebenwirkungen konsumiert.
\end{abstract}

Schlüsselwörter: drogeninduzierte Psychose, Hawaiianische Holzrose, Lisergsäurediethylamid, legale Highs, psychoaktive Substanzen

\section{Introduction}

The term "herbal or legal highs" is used as a common synonym for plants or part of plants containing psychoactive substances such as alkaloids or terpenes, which are consumed for their psychotropic effects. Herbal highs are often mistaken as organic, natural, safe, or even spiritual by the mostly adolescent or young-adult consumers of Western countries, despite possible serious adverse effects. In their countries of origin in South America or Asia, they have been traditionally used by traditional healers for shamanic rituals or as medicine plants (Grazianoa et al., 2017; Joseph et al., 2011).
Seeds of the Hawaiian Baby Woodrose ([HBWR]; botanical name: Argyreia nervosa) are marketed as "legal or herbal highs" and can be easily and cheaply purchased online from internet-based shops or directly in so-called headshops. According to a study from the UK on legal highs sold by UK online shops, HBWR seeds are among the psychedelic drugs most often purchased online in the UK (Schmidt et al., 2011). Prevalence data of consumption of HBWR seeds and lysergic acid amide containing psychoactive plant material respectively are not available in Germany. A recently published study that investigated the use of novel psychoactive substances including plant-derived psychoactive substances in patients who underwent 
inpatient detoxification treatment from illicit drugs in Germany reported a $2 \%$ lifetime overall misuse of psychoactive plant material in this population (Specka et al., 2020).

Available internet tutorials promise hallucinogenic trips and/or mind-expanding psychedelic experiences after consumption of HBWR seeds and recommend an amount of four to six HBWR seeds, which can be consumed crushed or whole or as a drink after soaking in water (Montagne, 2008; Wax, 2002). Information about possible adverse effects related to the consumption is generally not provided. In contrast, a user survey from New Zealand revealed that $1-4 \%$ of the consumer of herbal highs suffer from serious adverse effects requiring medical attention (Nicholson, 2006), and a recent study from US poison centers reported that $7 \%$ of the individuals who ingested HBWR seeds suffered from severe clinical side effects (Forrester, 2018).

Pharmacological research on HBWR seeds is rather limited. Available studies have shown that the seeds contain a variety of ergot alkaloids including lysergic acid amide (LSA), which is most probably the main psychoactive ingredient and chemically related to lysergic acid diethylamide (LSD). Though the mechanisms of action are not fully understood, LSA seems to affect the dopamine D2, adrenergic, and serotonergic receptors, with a preference for the 5-HT2 receptor subtype (Paulke et al., 2015). Mounting evidence also indicates that the alkaloid composition and concentration of LSA in HBWR seeds are highly variable. A study that analyzed LSA-concentration in HBWR seeds purchased from four different retailers showed that two batches of seeds contained only traces of LSA, whereas the other two batches contained a median concentration of $7.76 \mu \mathrm{g} \mathrm{LSA} / \mathrm{mg}$ HBWR and 9.28 $\mu \mathrm{g}$ LSA/mg HBWR, with a highly variable range of 3.75-16.03 $\mu \mathrm{g}$ LSA /mg HBWR and of 6.05-12.07 $\mu \mathrm{g}$ LSA $/ \mathrm{mg} \mathrm{HBWR}$, respectively, across the analyzed seeds (Kremer et al., 2012).

Information about clinical implications and course of intoxication-related psychiatric and somatic symptoms after HBWR seed consumption as well as therapy is sparse and mostly anecdotal. One Swedish study that systematically assessed 103 cases of suspected intoxications with psychoactive plant materials presenting in Swedish emergency departments over 4 years reported that $8(7.8 \%)$ of the individuals had consumed plant-derived LSA including HBWR, two of whom suffered from vomiting and mydriasis with a prolonged duration of intoxication of more than 10 h (Björnstadt et al., 2009). A French case series indicated that four LSA intoxications associated with psychiatric symptoms were reported in 2016 to the Poison Control Center of Toulouse, two of which resulted in hospitalization because of the severity of the psychiatric syndrome (Ponté \& Lapeyre-Mestre, 2017). In a laboratory study, four healthy and drug-naive individuals, aged 25-33 years, consumed a body-weight-adjusted amount of
$5.88 \mathrm{mg} / \mathrm{kg}$ body weight homogenized HBWR seeds,

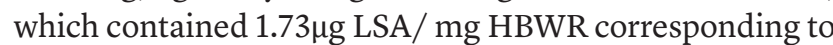
approximately 4 seeds of HBWR. All four probands displayed somatic symptoms like increased blood pressure, nausea, dizziness, and vomiting for a duration of up to 24 h. One proband additionally suffered from incoherent thoughts and speech, mood swings from euphoria to anxiety, derealization, and paranoid ideas, lasting about $9 \mathrm{~h}$ after ingestion of the HBWR seeds (Kremer et al., 2012). The few available, mostly cross-sectional clinical case studies of individuals with HBWR consumption also report somatic symptoms like nausea, vomiting, dizziness, headache, and tachycardia emerging after consumption of HBWR seeds. These were often combined with cognitive, affective, and psychotic psychiatric symptoms including losing track of time, reduced concentration span, impaired memory, anxiety and mood swings from euphoria to desperation, agitation, formal thought disorder with flight of ideas, incoherent or constricted thoughts, delusions, and intensified optical sensations or acoustic hallucinations. A case series published in French indicates four reports of intoxication with LSA with unintended severe psychiatric side effects in 2016 to the Poison Control Center of Toulouse.(Al-Assmar, 1999; Borsutzky et al., 2002; Gertsch et al., 2003; Göpel et al., 2003; Ponté \& Lapeyre-Mestre, 2017). A forensic report describes a 29 -year-old individual who had consumed HBWR seeds with alcohol and cannabis, jumped out of the window during intoxication, and died as a result of his injuries (Klinke et al., 2010). For more details, please see Table 1 .

\section{Case Report}

Here, we report on a 17-year-old female adolescent who was presented by her parents after misuse of HBWR seeds at the Emergency Outpatient Department of our clinics. They reported that the most prominent symptom provoking the referral was their daughter's unstable mood during the previous weeks. The day of the referral she had had an emotional breakdown at school and was crying desperately without being able to explain the reason why. She then confessed to her parents that 2 weeks ago she and her two sisters had consumed six seeds of HBWR each. In contrast to her, both sisters were feeling well and had no adverse effects after the HBWR seed consumption.

According to the detailed parents' report, during the week following the reported seed intake, their daughter was socializing more than usual, performed well at school, was in a euphoric and energetic mood and seemed more self-confident than usual. During the next few days, however, she developed increasing problems with concentra- 
Table 1. Clinical and forensic case reports of individuals with HBWR-seeds intoxication (published in English or German).

\begin{tabular}{|c|c|c|c|c|c|c|}
\hline & $\begin{array}{l}\text { Demographic } \\
\text { data }\end{array}$ & $\begin{array}{l}\text { Psychiatric } \\
\text { history, drug } \\
\text { abuse }\end{array}$ & $\begin{array}{l}\text { Details of HBWR } \\
\text { abuse }\end{array}$ & $\begin{array}{l}\text { Somatic } \\
\text { symptoms }\end{array}$ & $\begin{array}{l}\text { Psychiatric } \\
\text { symptoms }\end{array}$ & $\begin{array}{l}\text { Treatment and } \\
\text { outcome }\end{array}$ \\
\hline $\begin{array}{l}\text { Al-Assmar, } \\
1999\end{array}$ & Male, 18 yrs & & 12 seeds once & $\begin{array}{l}\text { Nausea, vomiting, } \\
\text { dizziness, tachy- } \\
\text { cardia hyperten- } \\
\text { sion nystagmus, } \\
\text { mydriasis }\end{array}$ & $\begin{array}{l}\text { Auditory hallucina- } \\
\text { tions; no further } \\
\text { information provided }\end{array}$ & $\begin{array}{l}\text { Overnight inpatient } \\
\text { treatment internal } \\
\text { ward, intravenous } \\
\text { saline; flashbacks } \\
\text { during } 4 \text { weeks }\end{array}$ \\
\hline $\begin{array}{l}\text { Göpel et al., } \\
2003\end{array}$ & $\begin{array}{l}\text { Female, } \\
17 \text { yrs }\end{array}$ & $\begin{array}{l}\text { Episodic canna- } \\
\text { bis misuse }\end{array}$ & 8 seeds once & $\begin{array}{l}\text { Nausea, physical } \\
\text { examination, ECG, } \\
\text { EEG, routine blood } \\
\text { parameter, urinary } \\
\text { drug screen with } \\
\text { regular results }\end{array}$ & $\begin{array}{l}\text { Disoriented for time, } \\
\text { concentration and } \\
\text { memory impaired, agi- } \\
\text { tated, anxious, mood } \\
\text { swings from deeply } \\
\text { despaired to euphoria, } \\
\text { flight of ideas, delu- } \\
\text { sions, intensified opti- } \\
\text { cal sensations } \\
\text { (colors), derealization }\end{array}$ & $\begin{array}{l}\text { Overnight psychiat- } \\
\text { ric inpatient treat- } \\
\text { ment, unspecified } \\
\text { low-dose neurolep- } \\
\text { tics; remission with- } \\
\text { in } 24 \mathrm{~h}\end{array}$ \\
\hline $\begin{array}{l}\text { Borsutzky } \\
\text { et al., } 2002\end{array}$ & Male, 21 yrs & $\begin{array}{l}\text { Cannabis } \\
\text { dependence, } \\
\text { episodic misuse } \\
\text { of ecstasy and } \\
\text { magic mush- } \\
\text { rooms, depres- } \\
\text { sive episodes }\end{array}$ & $\begin{array}{l}3-5 \text { seeds, } \\
3-4 \text { times }\end{array}$ & $\begin{array}{l}\text { Headache, tachy- } \\
\text { cardia, regular } \\
\text { CCT, EEG, ECG, } \\
\text { lumbar puncture, } \\
\text { somatic examina- } \\
\text { tion; drug screen: } \\
\text { cannabis }\end{array}$ & $\begin{array}{l}\text { Slowed and incoher- } \\
\text { ent thoughts, anxious, } \\
\text { depressed, tantalized, } \\
\text { agitated, tense, con- } \\
\text { stricted, laborious } \\
\text { thinking, delusions, } \\
\text { suicidal ideation }\end{array}$ & $\begin{array}{l}\text { Psychiatric inpa- } \\
\text { tient treatment, no } \\
\text { medication; remis- } \\
\text { sion within } 3 \text { weeks }\end{array}$ \\
\hline \multirow[t]{2}{*}{$\begin{array}{l}\text { Klinke et } \\
\text { al., } 2010\end{array}$} & Male, 21 yrs & & $\begin{array}{l}6 \text { seeds with } \\
\text { cannabis }\end{array}$ & & $\begin{array}{l}\text { Sense of well-being, } \\
\text { lost track of time; LSA } \\
\text { ( } 9 \text { h after consump- } \\
\text { tion): } 1.8 \mu \mathrm{g} / \mathrm{L} \text { (blood) }\end{array}$ & No information \\
\hline & Male, 29 yrs & & $\begin{array}{l}\text { Unknown } \\
\text { number of seeds } \\
\text { with cannabis } \\
\text { and alcohol }\end{array}$ & & $\begin{array}{l}\text { Got severely agitated, } \\
\text { jumped out of window } \\
4 \mathrm{~h} \text { after consumption; } \\
\text { LSA (13 h after con- } \\
\text { sumption): } 4.9 \mu \mathrm{g} / \mathrm{L} \\
\text { (blood), THC: } 22 \mu \mathrm{g} / \mathrm{L} \\
\text { (blood), ethanol: } 0.71 \\
\mu \mathrm{g} / \mathrm{L} \text { (blood) }\end{array}$ & Died from injuries \\
\hline
\end{tabular}

tion and thinking, seemed more and more anxious, and cried several times without evident reason. She withdrew from social contacts and suffered from sleeping problems and nightmares. Two days before referral to our Outpatient Department, her mental state deteriorated further with incoherent speech and thoughts. She was focused on fears regarding herself, closed ones, religious and moral issues, and was convinced of transferring harm to others.

During our assessment, the adolescent was cooperative, but afflicted, anxious, and suspicious. She reported that she had vomited shortly after consuming the HBWR seeds, and that she had consumed HBWR seeds approximately 6 months before without any negative effect. She further reported consumption of cannabis and alcohol together with friends up to once a week for recreational use. The date of the last cannabis consumption was not assessed. The psy- chopathological examination revealed that she was oriented for personal data (time and location not assessed) with a severely reduced concentration span and reduced shorttime memory, disrupted and incoherent thoughts and speech. She cried several times during the assessment upon noticing that she had lost track of her thoughts. She was fraught and slightly agitated and expressed ideas of reference. She did not report hallucinations or disturbances of self-experience and denied suicidal ideation as well as intention to harm others.

The parents reported a regular developmental history. The adolescent was attending a college with regular results and had attended competitive ballet training until 2 years before, which she had to stop because of an injury. The family atmosphere was described as friendly with no particular conflicts or strains. The parents reported no pre- 
existing medical or psychiatric conditions for her daughter. However, they described her as rather timid and avoidant in her social contacts, so that a social phobia was presumed previously. In the time following her quitting ballet training, she seemed depressed and withdrawn for a while. As part of the family history, the parents reported that the maternal grandfather suffered from one single episode of schizophrenia at the age of 18 years.

The adolescent was admitted for inpatient treatment. Electroencephalogram, electrocardiogram, cranial computed tomography, physical examination (besides a reduced BMI), and routine blood parameters did not reveal pathological findings. Drug screening at admission was negative for cannabis, amphetamine, cocaine, opioids, spice, benzodiazepines, and barbiturates. Liquor puncture was denied by the parents.

We cared for the patient within a psychosis setting with stimuli reduction, supportive talks if needed, and up to $2 \mathrm{mg}$ lorazepam daily, which decreased her inner tension. However, each tentative reduction of benzodiazepines increased the patient's delusional ideas, referential thoughts, and affective instability. We then additionally administered aripiprazole, which we gradually increased up to $10 \mathrm{mg}$. Simultaneously, we could gradually terminate the medication with lorazepam. This resulted in a complete remission of delusional ideas, disorganized thoughts, anxious and instable mood within 7 weeks, and the patient was discharged from inpatient treatment. She then visited our Outpatient Department for the following 28 weeks, where the medication with $10 \mathrm{mg}$ aripiprazole was continued. She reported an ongoing remission of the psychotic symptoms and stable mood, but problems with concentration during the weeks following the discharge, which resolved in the further course. She was able to attend school again and started working part-time additionally. Medication with aripiprazole was gradually reduced and completely discontinued 22 weeks after discharge. The patient remained stable and active for the following 6 weeks until week 28, when we terminated the regular psychiatric follow-up visits at our Outpatient Department.

\section{Discussion}

To our knowledge this is the first case report that describes an HBWR-seeds induced prolonged psychotic syndrome, provides information about the efficacy of pharmacological treatment with atypical neuroleptics and benzodiazepines and follow-up information until week 28.

The psychiatric syndrome of our adolescent patient, which was characterized mainly by severe cognitive symptoms, incoherent thoughts, delusions, anxious and unstable mood, corresponds to the psychiatric symptoms characteristically related to HBWRseeds intoxication described by available published case reports. However, a gradual increase of severity of psychiatric symptoms within 2 weeks after HBWR seed consumption which are not correlated to acute intoxication and the prolonged duration and severity of the substance-induced psychosis as well as the requirement of psychiatric inpatient treatment of several weeks and specific pharmacological treatment with atypical neuroleptics has not been reported before and adds empirical knowledge to the understanding of the range and possible severity of HBWR-seeds induced psychotic syndrome. We based the diagnosis exclusively on the clinical report of our patient and her parents, which may prove to be a limitation of the diagnostic validity. We could not confirm the consumption of HBWR seeds by an objective laboratory assessment as according to bioanalytical data LSA can be detected in urine only 1-24 h after consumption (Paulke et al., 2012), whereas the reported intake of HBWR seeds dated back 14 days. We also did not screen for other hallucinogenic drugs as there were no referring clinical hints but relied on the routine drug screening used by our department, which provided negative results for cannabis, amphetamine, cocaine, opioids, spice, benzodiazepines, and barbiturates. One limitation of diagnostic validity is that the described psychiatric syndrome is not specific to LSA but could also be associated with intoxication from other psychoactive substances, e.g., other hallucinogens or ketamine.

It is unclear why the presented adolescent patient did not react with psychiatric symptoms after her first consumption of HBWR seeds and why her sisters, who consumed the same number of HBWR seeds as she, unlike our patient did not experience any side effects. A possible explanation could be the variable LSA concentration in HBWR seeds (as described by Kremer et al., 2012), in combination with a genetic liability of our patient based on the positive family history for schizophrenic disorder or the repeated exposure to LSA as well as the anamnestically reported cannabis misuse. A recent meta-analysis also showed that $17 \%$ of individuals with first-episode, substance-induced psychosis were later diagnosed with schizophrenia or schizoaffective disorder (Fusar-Poli et al., 2016).

Treatment recommendations for LSA-induced psychiatric syndromes are not available, and the empirical evidence is limited. Most case studies report rather unspecific interventions like saline infusion and spontaneous remission of the psychiatric symptoms within a few hours. Goepel et al. (2003) reported treatment with low-potency neuroleptics and discussed the use of high-potency neuroleptics if needed. Kiefer and Benkert (2019) stated that benzodiazepines, clonidine, and naltrexone may be beneficial, and that an antipsychotic treatment should be started if needed. Con- 
cerning the positive outcome and complete remission of the psychotic symptoms of our patient, we argue for a combined treatment with benzodiazepines and atypical neuroleptics to manage LSA-induced psychosis.

Taken together, our case report shows that the negative side effects of HBWR are unpredictable, not necessarily related to the ingested number of seeds as the LSA concentration per seed varies considerably, may affect severely vulnerable individuals, and are often underestimated by adolescent consumers because of the positive notion of HBWR seeds as natural and legally available. Whereas the possession and consumption of LSA-containing seeds are not chargeable offenses in most countries, pure LSA is classified as a Class A drug, which are deemed the most dangerous drugs by the Misuse of Drugs Act in the United Kingdom and as a Schedule III drug and LSD precursor in the Controlled Substances Act of the United States (Controlled Substances Act, 1970). Much more information is needed about possible harmful effects related to so-called herbal or legal highs, especially for adolescents.

\section{References}

Al-Assmar, S.E. (1999). The seeds of the Hawaiian Baby Woodrose are a powerful hallucinogen. Archives of Internal Medicine, 159(17), 2090-2090.

Björnstadt, K., Hulten, P., Beck, O., \& Helander, A. (2009). Bioanalytical and clinical evaluation of 103 suspected cases of intoxications with psychoactive plant materials Evaluation of psychoactive plant intoxications. Clinical Toxicology, 47, 566-572.

Borsutzky, M., Passie, T., Paetzold, W., Emrich, H.M., \& Schneider, U. (2002). Hawaiian Baby Woodrose: (Psycho-) pharmacological effects of the seeds of Argyreia nervosa. A case-orientated demonstration. Der Nervenarzt, 73(9), 892-896.

Controlled Substances Act. (1970). Retrieved on 5 January 2021, STATUTE-84-Pg1236.pdf (govinfo.gov); Controlled Substances - Alphabetical Order (usdoj.gov).

Forrester, M.B. (2018). Argyreia nervosa exposures reported to Texas poison centers. Journal of addictive diseases, 37(3-4): 160164. http://doi.10.1080/10550887.2019.1640057.

Fusar-Poli, P., Cappucciati, M., Rutigliano, G., Heslin, M., Stahl, D., Brittenden, Z., Caverzasi, E., McGuire, P., \& Carpenter, W.T. (2016). Diagnostic stability of ICD/DSM first episode psychosis diagnoses: Meta-analysis. Schizophrenia Bulletin, 42(6), 1395-1406.

Gertsch, J.H., \& Wood, C. (2003). Case report: an ingestion of Hawaiian Baby Woodrose seeds associated with acute psychosis. Hawaii Medical Journal, 62(6), 127-129.

Göpel, C., Maras, A., \& Schmidt, M. H. (2003). Hawaiian Baby Woodrose: Case report of an argyreia nervosa induced toxic psychosis. Psychiatrische Praxis, 30(4), 223-224.

Grazianoa, S., Orsolinib, L., Rotoloa, M.C, Tittarellie, R., Schifanob, F., \& Pichini, S. (2017). Herbal highs: Review on psychoactive effects and neuropharmacology. Current Neuropharmacology, 15, 750-761.

Joseph, A., Mathew, S., Skaria, B., \& Sheeja, E.C. (2011). Medicinal uses and biological activities of Argyreia speciosa Sweet (Hawaiian Baby Woodrose): An overview. Indian Journal of Natural Products and Resources, 2(3), 286-291.
Kiefer, F., \& Benkert, O. (2019). Psychiatric syndromes induced by hallucinogenic drugs (LSD, mescaline, psilocybine and related drugs). In O. Benkert \& H. Hippius (Eds.), Kompendium der Psychiatrischen Pharmakotherapie (12th ed., pp. 724-726). Springer.

Klinke, H. B., Müller, I. B., Steffenrud, S., \& Dahl-Sørensen, R. (2010). Two cases of lysergamide intoxication by ingestion of seeds from Hawaiian Baby Woodrose. Forensic Science International, 197(1-3), e1-e5.

Kremer, C., Paulke, A., Wunder, C., \& Toennes, S.W. (2012). Variable adverse effects in subjects after ingestion of equal doses of Argyreia nervosa seeds. Forensic Science International, 214(13), e6-e8.

Montagne, M. (2008). Drugs on the Internet. I: introduction and websites on psychedelic drugs. Substance Use Misuse, 43,17-25.

Nicholson, T.C. (2006). Prevalence of use, epidemiology and toxicity of "herbal party pills" among those presenting to the emergency department, Emergency Medicine Australasia, 18, 180-184.

Paulke, A., Kremer, C., Wunder, C., \& Toennes, W.T. (2012). Analysis of lysergic acid amide in human serum and urine after ingestion of Argyreia nervosa seeds. Analytical and Bioanalytical Chemistry, 404(2), 531-538.

Paulke, A., Kremer, C., Wunder, C., Wurglics, M., Schubert-Zsilavecz, M., \& Toennes, S.W. (2015). Studies on the alkaloid composition of the Hawaiian Baby Woodrose Argyreia nervosa, a common legal high. Forensic Science International, 249, 281-293.

Ponté, C., \& Lapeyre-Mestre, M. (2017). Psychoactive effects of "legal high": About lysergic acid amide (LSA). Therapie, 72(5), 605-660.

Schmidt, M.M., Sharma, A., Schifano, F., \& Feinmann, C. (2011). "Legal highs" on the net-Evaluation of UK-based Websites, products and product information. Forensic Science International, 206(1-3), 92-97.

Specka, M., Kuhlmann, T., Sawazki, J., Bonnet, U., Steinert, R. Cybulska-Rycicki, M., Eich, H., Zeiske, B., Niedersteberg, A., Schaaf, L., \& Scherbaum, N. (2020). Prevalence of novel psychoactive substance (NPS) use in patients admitted to drug detoxification treatment. Frontiers in Psychiatry, https://doi.org/10.3 389/fpsyt.2020.00569

Wax, P.M. (2002). Just a click away: recreational drug web sites on the internet. Pediatrics, 109, e96.

\section{History}

Manuscript submitted: 01.12.2020

Accepted after revision: 28.01.2021

Published online: 04.03.2021

\section{Conflicts of interests}

No conflicts of interest exist.

\section{Funding}

Open access publication enabled by University Medical Center Mainz.

\author{
Prof. Dr. med. Esther Sobanski \\ University Medical Center Mainz \\ Langenbeckstraße 1 \\ 55131 Mainz \\ Germany
}

esther.sobanski@unimedizin-mainz.de 